\title{
THE RECURSIVE FORMATION OF OLD ENGLISH NON-VERBAL CATEGORIES. PRODUCTIVITY AND CONSTRAINTS ${ }^{1}$
}

\author{
Raquel Vea Escarza \\ University of La Rioja \\ Raquel.vea@unirioja.es
}

\begin{abstract}
This paper aims at analysing the recursivity in the formation of non-verbal categories, more specifically, of nouns and adjectives in Old English. Pounder's (2000) model, known as Process and Paradigm Model, provides the formal representation of recursive operations. The data of analysis consist of a total of 388 recursive nouns and adjectives, 11 of which undergo a two-level recursivity, or slot-II recursivity. Both in the case of nouns and adjectives, suffixation has a clearly preeminent role over prefixation. As for nouns, the suffix -nes is the most frequent one in number of tokens, whereas - $\partial$ is the one that combines with a greater number of suffixes in prefinal position. Regarding adjectives, -lic is by far the suffix present in a higher number of predicates, and also the one that undergoes a wider variety of different recursive patterns, what evinces that there is correlation between a high type frequency and the assignment of a high number of different recursive patterns. Positional constraints affect -nes and -lic, since none of them can occur in a position other than final. A semantic interpretation of recursive suffixation leads to assign a semantic effect of this phenomenon when it applies to nouns, and a pragmatic one in the case of adjectives.
\end{abstract}

Keywords: Recursivity, productivity, constraints, affixation, Old English.

1 This research has been funded through the project FFI2011-29532, which is gratefully acknowledged. 


\title{
LA FORMACIÓN RECURSIVA DE CATEGORÍAS NO VERBALES EN INGLÉS ANTIGUO. PRODUCTIVIDAD Y RESTRICCIONES
}

\begin{abstract}
RESUMEN. Este artículo pretende analizar la recursividad en la formación de palabras de categoría no verbal, más concretamente en los nombres y adjetivos del inglés antiguo. El modelo de Pounder (2000), conocido como Modelo de Proceso y Paradigma, sustenta la representación formal de las operaciones recursivas. Los datos de análisis incluyen un total de 388 nombres y adjetivos recursivos, once de los cuales presentan recursividad de dos niveles. Tanto en el caso de los nombres como en el de los adjetivos, la sufijación tiene un papel más relevante que la prefijación. En cuanto a los nombres, el sufijo - nes es el más frecuente en número de ocurrencias, mientras que -z es el que combina con un mayor número de sufijos en posición prefinal. Respecto a los adjetivos, -lic es, con mucha diferencia, d sufijo que aparece en un mayor número de predicados, y también es al que interviene en un mayor número de patrones gijales recursivos, lo que evidencia que hay correlación entre una alta frecuencia de tipo y la asignación de un alto número de patrones recursivos distintos. Existen restricciones posicionales que afectan a-nes y a-lic, pues ninguno de ellos puede ocurrir en una posición no final. Una interpretación semántica de la sufijación recursiva nos lleva a asignar un efecto semántico a este fenómeno cuando ocurre en los nombres, mientras que en el caso de los adjetivos el efecto es más bien pragmático.
\end{abstract}

Palabras clave: Recursividad, productividad, restricciones, afijación, inglés antiguo.

Received 23 February 2015

Revised version accepted 18 April 2015

\section{STATE OF THE ART AND AIMS OF THE RESEARCH}

Recursivity is a linguistic phenomenon which has drawn more attention from syntax (thus van der Hulst ed. 2010) than from semantics. Lieber's (2004) study in the relationship between morphology and lexical semantics is exceptional in dealing with the recursivity of word-formation processes. This author distinguishes between the lexical semantic body and the lexical semantic skeleton of a formation. The lexical semantic body is encyclopaedic and non-decompositional, whereas the lexical semantic skeleton is decompositional, hierarchically arranged and oriented towards those aspects of meaning that have consequences for the syntax. As Lieber (2004: 10) puts it, the body will include many of the aspects of meaning that Pustejovsky encodes in his Qualia Structure. Lieber (2004: 161) also proposes the Redundancy Restriction, which excludes from affixation the semantic content that 
is already present in the base of derivation, although she admits that the repetition of the same features is possible if the new formation is useful and interpretable. In this view, once all phonological, semantic and syntactic restrictions have applied, more affixes can be attached in order to transpose a useful concept or augment the meaning of the base of derivation. This is to say that recursivity has to be motivated, in such a way that derivatives can be further derived for semantic or pragmatic reasons.

With this background, the aim of this article is to address the question of recursivity in Old English and, more specifically, to describe the types of recursive formations that can be found in the nominal and adjectival lexicon as well as to explain what restrictions apply and what the function of the derivation of derived bases is. The explanation will pursue the same line as Lieber (2004) in the sense of attributing the motivation of recursivity to semantic or pragmatic reasons.

The outline of the article is as follows. Section 2 focuses on terminological and methodological aspects relevant for the analysis of recursivity in the formation of Old English nouns and adjectives, such as the concept of recursivity itself, morphological operations and recursivity levels. This section also presents the data of analysis. Section 3 describes the operations required in the representation of recursivity at two levels. Section 4 concentrates on the relationship between recursivity and productivity and provides a motivation for the recursive formation of nouns and adjectives. Finally, section 5 summarizes the main conclusions of the research.

\section{RESEARCH METHODOLOGY AND DATA OF ANALYSIS}

The analysis presented in this article is based on the structural-functional framework of morphology proposed by Martín Arista (2008, 2009, 2010a, 2010b, 2011a, 2011b) and, more specifically, on two ideas central to this framework. Firstly, complex words constitute hierarchically arranged structures in which categories and functions can be distinguished at several levels. And, secondly, the defining properties of derivational morphology are recategorization and recursivity. Regarding recursivity, it is necessary to clarify certain terminological issues. On the one hand, the concept of recursivity must be differentiated from that of recursion, the latter being preferred by authors such as van der Hulst (2010), who underlines the dynamic aspect of recursion and its contribution to the creative dimension of language. However, when dealing with a historical language, as is the case with Old English, the term recursivity is more appropriate since there is no creation of new words but morphological relations between lexical elements. Thus, recursivity, both at a restrictive and general level, implies 
the repetition of a rule. In general terms, recursivity in word formation entails the derivation of a derived derivative base, regardless of the morphological processes involved. A further methodological aspect that requires attention is the representation of lexical recursivity. To begin with, the analysis of recursivity carried out in this research is strictly synchronic. Martín Arista (2012, 2013, 2014) defines lexical recursivity as the derivation of derived bases, which constitutes a property of lexical paradigms. For a formation to be considered recursive, a certain process needs to be repeated, such as prefixation on prefixation or suffixation on suffixation. Apart from the restriction stipulating that recursivity requires that the output of a derivational process needs to be inputed to the process in question, lexical derivation is gradual: an affix is attached per process. A distinction must be made, therefore, between simplex forms (no affix), non recursive formations (one affix), recursive formations with non recursive base (two affixes) and recursive formations with recursive base (three affixes). The highest degree of complexity identified in the recursive word-formation of Old English is represented in figure 1, which presents ealdordomlicnes 'authority, control' by following the diagram model adopted by van der Hulst (2010) for lexical recursivity. As the figure shows, the suffixed noun ealdordomlicnes is recursively derived from the previously derived adjective ealdordomlic 'preeminent', which is created, in turn, out of the already suffixed noun ealdordom 'power', morphologically related to the derivative base EALDOR 1 'elder'.

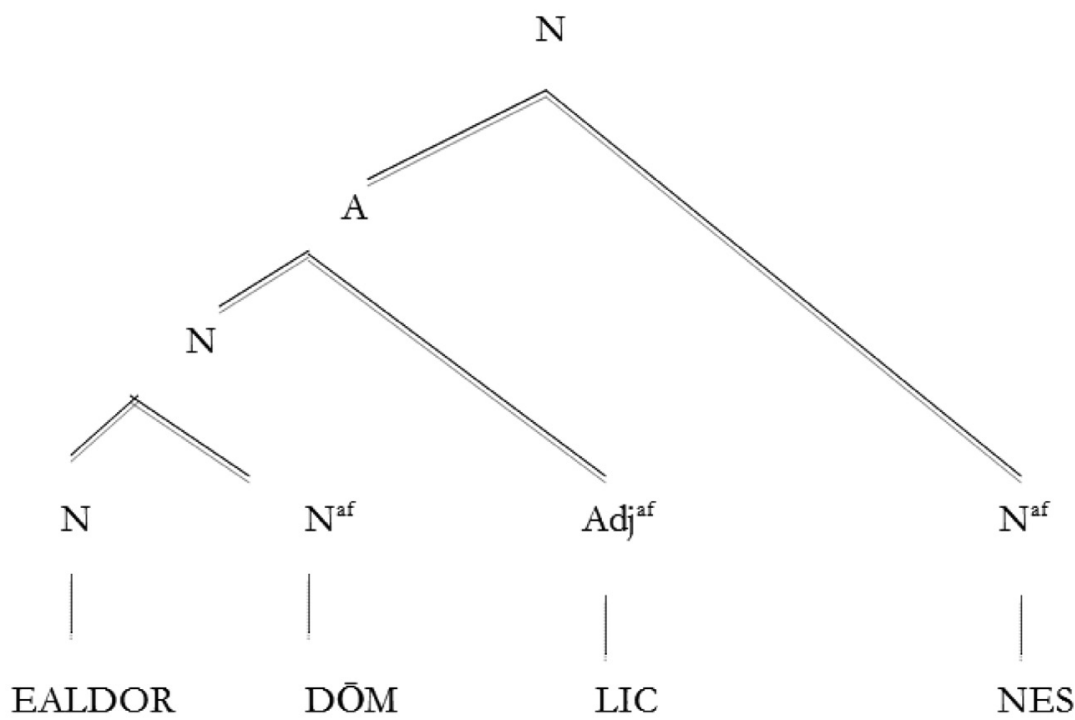

Figure 1. Representation of the recursive noun ealdordomlicnes. 
Since van der Hulst (2010) is not concerned with the lexical and morphological aspects of the representation, the framework of paradigmatic morphology developed by Pounder (2000) is used in order to account for the operations and rules relevant for the derivational morphology of Old English. Figure 2 shows the morphological operation which has been used to represent the word formation processes:

$$
\begin{aligned}
& <\mathrm{X} \rightarrow \mathrm{Y} ;{ }^{\prime} \mathrm{FR} \text { '; } \Sigma>\text {; 'WFO }{ }_{\mathrm{X}}^{\prime} ; \Sigma> \\
& <f\left({ }^{\prime} \mathrm{X}\right) ; \mathrm{SR}_{\mathrm{X}}{ }^{\prime} ; \Sigma> \\
& <\Sigma_{\mathrm{X}} \rightarrow \Sigma_{\mathrm{Y}} ;{ }^{\prime} \Sigma \mathrm{R}_{\mathrm{X}}{ }^{\prime} ; \Sigma>
\end{aligned}
$$

Figure 2. The morphological operation.

Lexemes are signs with the form $<\mathrm{X}$; ' $\mathrm{X}$ '; $\Sigma>$, where the signifier is made out of a group of complex morphemes. The morphological operation in Figure 2 indicates the base and the affix $(\mathrm{X} \rightarrow \mathrm{Y})$, the derivative function $\left(f\left({ }^{\prime} \mathrm{X}\right)\right)$ and the category change $\left(\Sigma_{\mathrm{X}} \rightarrow \Sigma_{\mathrm{Y}}\right)$, together with the relevant restrictions. The morphological rules may have up to four different types of signifiers: (i) signifiers with the form $\mathrm{X} \AA \mathrm{y}$ (derivation), where $y$ is an affix; (ii) signifiers with the form $\mathrm{X} \rightarrow \mathrm{X}$ (conversion); (iii) signifiers with the form $\mathrm{a} \rightarrow \mathrm{b}$ (modifying processes), where $\mathrm{a}$ and $\mathrm{b}$ are phonological units in $\mathrm{X}$ and $\mathrm{Y}$ respectively and are defined in $\Sigma$; and (iv) signifiers with the form $\mathrm{X} \AA \mathrm{Y}$ (composition), where $\mathrm{X}$ and $\mathrm{Y}$ are stems. Two levels of recursivity can be distinguished: recursivity with a non-recursive base and recursivity with recursive base. The first level requires slot-I and slot-II, and the second one slot-III. An example of each level can be seen in Figure 3 and Figure 4, respectively.

$$
\begin{array}{ll}
<\text { under } \AA \mathrm{x}>; & \mathrm{O}_{1}^{\prime} \text { ';.s.c.: } \mathrm{N} \\
<\operatorname{MIN}\left(\mathrm{X}^{\prime}\right)> & \text { O.c.: slot }-\mathrm{II} \text { [tō- slot }-\mathrm{I}] \\
<\Sigma_{\mathrm{N}} \rightarrow \Sigma_{\mathrm{N}}> & \text { undertōdal from TŌDĀL 'partition' }
\end{array}
$$

Figure 3. Slot-I operation in undertōdal 'secondary division'.

$$
\begin{array}{ll}
<\mathrm{X} \AA \text { nes }>; & \text { 'O '; s.c.: Adj } \\
<\mathrm{REL}\left(\mathrm{X}^{\prime}\right)> & \text { O.c.: slot }- \text { III [-ð slot-II [-lic slot -I]] } \\
<\Sigma_{\text {Adj }} \rightarrow \Sigma_{\mathrm{N}}> & \text { fracoðlic from FRACOĐ 1 'vile' }
\end{array}
$$

Figure 4. Slot-II operation in fracoðlicnes 'vileness'.

The analysis that follows distinguishes the following affixes presented in Figure 5, 6 and 7, which draw on the inventories provided by Jember et al. (1975), Kastovsky 
(1992), Lass (1994) and Quirk and Wrenn (1994). Textual realizations and variants are given between brackets.

Ā- (ā-), $\bar{Æ}-(\bar{Æ}-)$, ÆFTER- (æfter-), ÆT- (æt-), AND- (am-, an-, and-), ANTE(ante-), ARCE- (arce-), BE- (bi-, bī-), EALL- (æl-, al-, eall-), ED- (ed-), EL- (æl-, el-), FOR- (for-, fōr-, fore-), FORE- (for-, fore-, fōre-), FORĐ(forð-), FRAM- (fram-), FRĒA- (frēa-), FUL- (ful-, full-), GEAN- (gean-, gēan-), HEALF- (healf-), IN- (in-, inn-), MID- (med-, mid-), Ō- (ō-), OF(æf-, of-), OFER- (ofer-), ON- (on-), OR- (ō-, or-), SĀM- (sam-, sām-), SIN- (sin-, sine-), SUB- (sub-), TŌ- (tō-), TWI- (twi-), ĐRI- (ðri-, ðry-), ĐURH- (ðurh-), UN- (and-, on-, un-), UNDER- (under-), ŪP- (up-, ūp-), ŪT- (ūt-, ùð-), WAN- (wan-), WIĐ- (wið-), WIĐER- (wiðer-), YMB(ymb-, ymbe-).

Figure 5. Old English prefixes.

-BORA (-bior, -bora), -DŌM (-dōm), -ED (-ad), -EL (-el, -eld, -ele, -elle, -il, -l, -la, -le, -1l, -lle, -ol), -ELS (-els, -ls), -EN (-en, -n), -END (-d, -en, -end, -ende, -iend, -liend, -nd), -ERE (-e, -er, -era, -ere, -igere, -lere, -lēre, -re), -ESSE (-esse), -ESTRE (-estre, -istre, -stre, -ystre), -ETT (-et, -eta, -ett, -t, -tt), -FUL (-ful), -HĀD (-hād), -ICGE (-ecge, -icge, -ige), -IG (-ig), -INCEL (-incel), -ING (-ing, -unga, -inga), -LING (-ling), -NES (-enes, -es, -nes, -ness, -nis, -nys, -nyss, -s), -RǢॄDEN (-ræēden), -SCIPE (-scipe, -scype), -SUM (-sum), -ð (-að, -d, -ed, -ot, -oð, -оða, -t, -ð, -ða, -ðе, -ðо, -ðu, -uð), -UNG (-ng, -ung), -WIST (-wist).

Figure 6. Old English nominal suffixes.

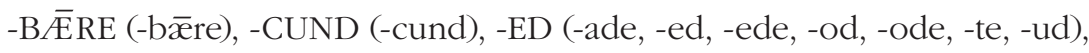
-EL (-el, -ol, -ul), -EN (-en), -END (-end, -igend), ENDE (-ende, -iende), -ERNE (-ern, -erne), -FÆST (-fæest), -FEALD (-feald), -FUL (-ful), -IC (-ic), -IG (-ig, -ige), -IHT (-eht, -ehte, -iht, -ihte), -ING (-ing), -ISC (-isc), -LEAS (-lēas), -LIC (-lic), -OR (-or), -SUM (-sum), -WEARD (-weard), -WELLE (-welle), WENDE (-wende).

Figure 7. Old English adjectival suffixes.

In order to search for recursive formations with the affixes listed in Figure 5, 6 and 7 , the data of analysis have been retrieved from the lexical database of Old English Nerthus (www.nerthusproject.com), consulted in September 2014. The data 
comprise a total of 4,370 nouns and 3,218 adjectives derived by prefixation or suffixation. By process, a total of 2,001 are prefixed words and 5,587 are suffixed ones. Focusing on recursive predicates, there are 257 recursive nouns and 131 recursive adjectives, thus making a total of 388. Out of the 388 recursive nouns and adjectives, 377 are recursive formations with non recursive base (two affixes), whereas the remaining 11 are recursive with recursive base (three affixes).

\section{STEPWISE ANALYSIS OF DERIVATION}

The analysis of both the prefixation and the suffixation of the lexical classes under scrutiny has been carried out in two steps: in the first place, non-recursive derivation has been examined, including the primary base of affixation and the affix in question; in the second place, the affixation base and the affix that gives rise to the recursive formation have been considered, as is illustrated in figure 8.

\begin{tabular}{|c|c|c|c|}
\hline Derivative & AfFixation Base & Primary base & $\begin{array}{r}\text { SEQUENCE OF } \\
\text { AFFIXES }\end{array}$ \\
\hline undertōdal $(\mathrm{N})$ & tōdāl (N) & $(g e) d \bar{a} l(\mathrm{~N})$ & \\
\hline 'secondary division' & 'partition' & 'division’ & under-tō- \\
\hline $\begin{array}{l}\text { bisceophädung }(\mathrm{N}) \\
\text { 'episcopal ordination' }\end{array}$ & $\begin{array}{l}\text { bisceophād }(\mathrm{N}) \\
\text { 'bishophood' }\end{array}$ & bisceop 'bishop' (N) & $-b \bar{a}-d u n g$ \\
\hline $\begin{array}{l}\text { healfsinewealt (Adj) } \\
\text { 'semicircular' }\end{array}$ & $\begin{array}{l}\text { sinewealt (Adj) } \\
\text { 'round' }\end{array}$ & $\begin{array}{l}\text { wealte }(\mathrm{N}) \\
\text { 'ring' }\end{array}$ & healf-sine- \\
\hline $\begin{array}{l}\text { wilsumlic (Adj) } \\
\text { 'desirable' }\end{array}$ & $\begin{array}{l}\text { wilsum (Adj) } \\
\text { 'desirable' }\end{array}$ & $\begin{array}{l}\text { will } 1(\mathrm{~N}) \\
\text { 'mind, will' }\end{array}$ & -sum-lic \\
\hline
\end{tabular}

Figure 8. Affixation base and primary base in the derivation of nouns and adjectives.

The analysis has identified a number of sequences or patterns of recursivity, which are different depending on the derivative process involved. Beginning with nouns, a total of three prefixal recursive patterns emerge, which are exemplified in Figure 9, together with a predicate containing the recursive sequence in question:

ofer-healf- (oferhealfhèafod 'crown of the head'), on-un- (onunwìsdòm 'folly'), under-tō- (undertōdal 'secondary division')

Figure 9. The recursive prefixation of nouns.

In Figure 10, the fifty-five different recursive patterns for suffixed nouns are provided, as well as an instance of each of them: 


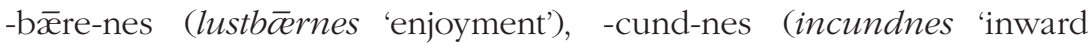
conviction'), -dōm-end (selfdèmende 'monk subject to his own rules'), -dōm-ere (selfdēmere 'monk subject to his own rules'), -dōm-hād (ðēowdōmhād 'service'), -dōm-nes (lāecedōmnes 'cataplasm'), -dōmscipe (ealdordōmscipe 'office of alderman'), -el-ett (ðy felett 'thicket'), -el-nes (rēafolnes 'rapacity'), -el-ung (setlung 'sitting'), -en-dōm (bōe ðendōm 'heathendom'), -en-ere (cristnere 'one who performs the rite of crīstnung'), -en-nes (frēcennes 'harm'), -en-rǣen (moestenrāeden 'right of feeding swine'), -en-scipe (geliefenscipe 'justification'), -en-ung (crīstnung 'christening'), -end-dōm (reccenddōm 'governance'), -end-

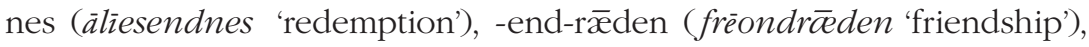
-end-scipe (frēondscipe 'friendship'), -ere-hād (ðrōwerhād 'martyrdom'), -ere-nes (gîfernes 'greediness'), -ett-nes (änetnes 'solitude'), -ett-ung (ligetung 'lightning'), -fæst-en (hëahfoesten 'fortified town'), -fæst-nes (staðolfoestnes 'stability'), -fæst-ung (staðolfoestnung 'foundation'), -fealdnes (felafealdnes 'multitude'), -ful-nes (wistfullnes 'good cheer'), -hādnes (geoguðhādnes 'state of youth'), -hād-ung (bisceophādung 'episcopal ordination'), -ig-dōm ( hāligdōm 'holiness'), -ig-nes (wèrignes 'weariness'), -ing-hād (ceðelinghād 'princely state'), -ing-nes (līhtingnes 'lightness of taxation'), -isc-nes (menniscnes 'state of man'), -lēas-nes (feohlēasnes 'want of money'), -lēas-ð (wîflèast 'lack of women'), -lic-nes (medemlicnes 'mediocrity'), -lic-ung (gemetlicung 'adjustment'), -rǣeden-nes (gefêrrōe dnes 'society'), -sum-nes (lufsumnes 'pleasantness'), -ð-dōm (ðēowotdōm 'service'), -ð-el (tibtle 'accusation'), -ð-en (tybten 'incitement'), -ð-end (tybtend 'inciter'), -ð-ere (tybtere 'inciter'), -ð-ing (tybting 'incitement'), -ð-ling (ðе̄owtling 'servant'), -ð-nes (tybtnes 'inward impulse'), -ð-rǣen

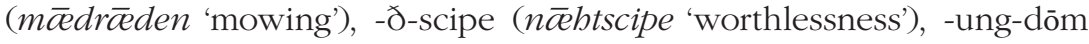
(wiccungdōm 'witchcraft'), -ung-nes (gegearwungnes 'preparation'), -weard-nes (tōweardnes 'future')

Figure 10. The recursive suffixation of nouns.

To continue with, the patterns applying to recursive adjectival formations are dealt with. The analysis has identified three different ones for prefixation, as can be seen in Figure 11.

healf-sine- (healfsinewealt 'semicircular'), un-and- (unandweard 'not present'), un-for- (unforcūð 'reputable')

Figure 11. The recursive prefixation of adjectives. 
A total of thirty-five different patterns are needed to account for the recursivity of suffixed adjectives in Old English. They are presented in Figure 12, along with an instance of each:

-b̄̄re-lic (cwildberendlic 'deadly'), -cund-lic (eorðcundlic 'earthly'), -dōmlic (ealdordōmlic 'preeminent'), -ed-lic (fracoðlic 'base'), -el-ed (bwyrflede

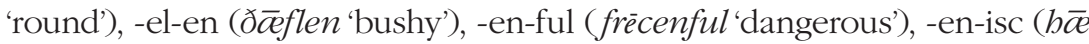
ðenisc 'heathenish'), -en-lēas (ðèodenlèas' 'without a ruler'), -en-lic (ieldendlic 'dilatory'), -en-weard (linenweard 'clad in linen'), -end-lēas (frēondlēas 'friendless'), -end-lic (onföndlic 'to be received'), -ere-en (forligeren 'fornicating'), -ere-lic (forligerlic 'unchaste'), -fæest-lic ( $\bar{a} w f \circ e s t l i c$ 'lawful'), -feald-lic ( bundfealdlic 'hundred-fold'), -ful-lic ( fäcenfullic 'deceitful'), -hādlic (fōemnhädlic 'maidenly'), -ig-fæest (wlitigfoest 'of enduring beauty'), -ig-lic (syndriglic 'special'), -iht-ig (clifihtig 'steep'), -isc-lic (mennisclic 'human'), -lēas-lic (scamléaslic 'shameless'), -ol-lic (swicollic 'fraudulent'), -or-ig (heolstrig 'shadowy'), -scipe-lic (gesinsciplic 'conjugal'), -sum-lic (angsumlic

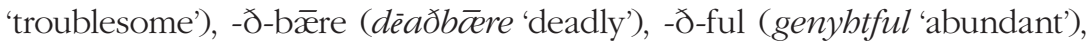
-ð-ig (cystig 'charitable'), -ð-lēas (cystlēas ‘worthless'), -ð-lic (forstlic 'glacial'), -ð-sum ((ge)nyhtsum 'abundant'), -weard-lic (inweardlic 'internal')

Figure 12. The recursive suffixation of adjectives.

Within the framework of Pounder's (2000) paradigmatic morphology, the affixes that are attached to previsouly affixed words require an extra position, called slot -II, since the slot -I position is allocated to the affixes inserted in the previous stage of the operation. The first part of the operation in (7) represents the affixation process, the second one the derivative function and the third one the (re)categorization pattern. The symbol $\AA$ stands for the affixation, that is why it appears after a prefix or goes before a suffix. The right column shows two types of restrictions: stem conditions (s.c.), including the lexical class of the base and order conditions (o.c.), which determine the slot. In the following figures, operations are grouped by affix, and all the derivatives of each of them are listed below.

Beginning with prefixation, the operations in Figure 13 illustrate this derivative phenomenon for nouns and adjectives:

$$
\begin{array}{ll}
<\text { on } \AA \mathrm{x}>; \mathrm{O}_{5} ; & \text { s.c.: } \mathrm{N} \\
<\mathrm{INTENS}\left(\mathrm{X}^{\prime}\right)> & \text { o.c.: slot }-\mathrm{II} \text { [un- slot -I] } \\
<\Sigma_{\mathrm{N}} \rightarrow \Sigma_{\mathrm{N}}> & \text { onunspēed from SPĒD 'luck' } \\
\text { onunspéd 'indigence' } &
\end{array}
$$




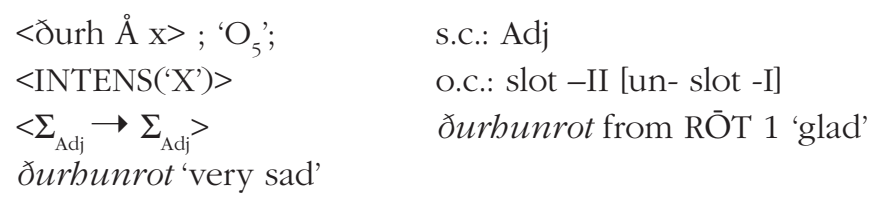

Figure 13. Recursive prefixation in slot- II of nouns and adjectives.

The derivatives exemplified in Figure 13 require slot -II, given that slot -I is occupied by the prefix un- in both cases. In the first case, the prefix un- is attached to a nominal base, SPED, whereas in the second case, the same prefix is attached to an adjectival base, RŌT 1.

Regarding the operations involved in recursive suffixation, the ones represented in Figures 14 and 15 require slot -II, as a result of the insertion of a suffix in slot -I:

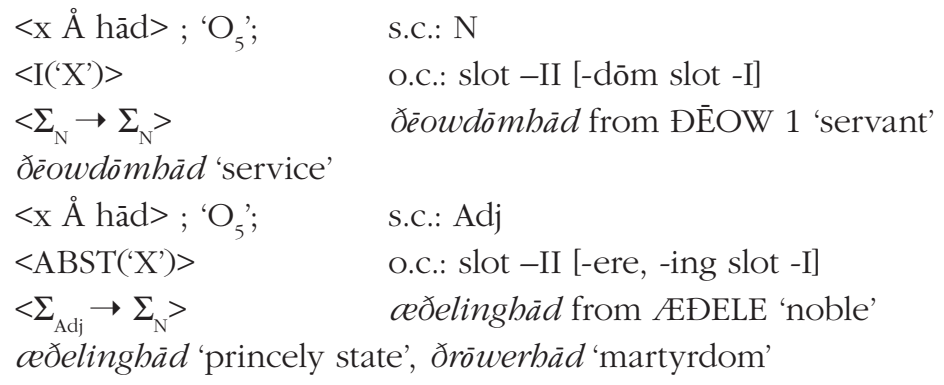

Figure 14. Recursive suffixation slot- II of nouns.

\begin{tabular}{|c|c|}
\hline <x Å lēas> ; 'O', & s.c.: Adj \\
\hline$<\operatorname{PRIV}\left({ }^{\prime} \mathrm{X}\right)>$ & o.c.: slot -II [-en, -end, -ð slot -I] \\
\hline$<\Sigma_{\mathrm{Adj}} \rightarrow \Sigma_{\mathrm{Adj}}>$ & freondlēas from FRĒO 1 'free' \\
\hline
\end{tabular}

Figure 15. Recursive suffixation in slot- II of adjectives.

The operation in Figure 14 illustrates the formation of derivatives in -hād, including the only predicate that contains the affixal sequence -dōm-hād and the ones with -ing-hād and -ere-hād. The operation in Figure 15 corresponds to adjectival derivatives in -leas. Whereas recursivity with non recursive base is described in 
terms of slot -II position, recursivity with recursive base requires slot -III position. Examples of nouns and adjectives having a recursive base have been exclusively identified in suffixation. Figure 16 provides the rules and operations corresponding to double recursivity in nouns and adjectives.

$$
\begin{aligned}
& <\mathrm{x} \AA \mathrm{\partial}>\text {; ' } \mathrm{O}_{5} \text {; } \quad \text { s.c.: Adj } \\
& <\mathrm{PROP}\left(\mathrm{X}^{\prime}\right)>\quad \text { O.c.: slot -III [-end slot-II [-lēas slot -I]] } \\
& <\Sigma_{\mathrm{Adj}} \rightarrow \Sigma_{\mathrm{N}}>\quad \text { frēondléast from FRĒO } 1 \text { 'free' } \\
& \text { frēondlēast 'want of friends' } \\
& <\mathrm{x} \AA \text { lic }>\text {; 'O '; } \quad \text { s.c.: } \mathrm{V} \\
& <\text { PROP('X') } \quad \text { O.c.: slot -III [-ð slot-II [-end slot -I]] } \\
& <\Sigma_{\mathrm{V}} \rightarrow \Sigma_{\mathrm{Adi}}>\quad \text { tybtendlic from (GE)TĒON } 1 \text { 'to pull' } \\
& \text { tybtendlic 'persuading' }
\end{aligned}
$$

Figure 16. Double recursivity in nouns and adjectives.

A total of 11 predicates, three of which are nouns and eight adjectives, undergo three level recursivity, that is, three suffixes partake in the derivation. The nouns in question are dēaðbēernes 'deadliness', dēaðlicnes 'mortal state', ealdordömlicnes 'authority', fracoðlicnes 'vileness', frēondlēast 'want of friends', gesēelignes 'happiness', godcundlicnes 'divine nature', mennisclicnes 'state of man'. The adjectives that

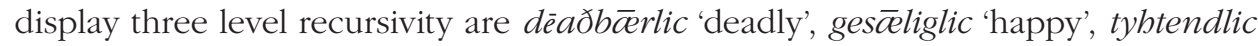
'persuading'.

All in all, recursivity in Old English noun and adjective formation is a matter of suffixation rather than prefixation: there are fifty-eight affix combinations in noun formation and thirty-eight in adjective formation. There are instances of double recursivity both in the formation of nouns and adjectives, although noun formation outnumbers adjective formation. Double recursivity is restricted to suffixation. These results coincide with the main aspects of Martín Arista's (2008) predictions on Old English derivational morphology. Torre Alonso, in his description of Old English nominal morphology (2009, 2010, 2011a, 2011b), suggests a maximum of three morphological positions to the right of the word, although the third position of Torre Alonso's analysis is reserved to inflection, whereas the data analyzed here require a derivational third position to the right of the word. To close the section devoted to the stepwise analysis of recursivity in noun and adjective formation, it must be remarked that the most frequent suffix in noun formation is -nes, while -lic qualifies as the most frequent in adjective formation. 


\section{PRODUCTIVITY AND CONSTRAINTS ON RECURSIVITY}

The analysis of recursivity in the formation of affixed nouns and adjectives indicates that the number of recursive patterns which an affix enters is directly proportional to its frequency of type. This is clearly the case with -nes, which is attached to 190 derived words in Old English. Figure 17 lists all the affix combinations that stage -nes in final position and provides an illustration for each.

-b̄̄ere-nes (cwealmbēernes 'mortality'), -cund-nes (godcundnes 'divine nature'), -dōm-nes (lāecedōmnes 'cataplasm'), -ed-nes (fracoðnes 'vileness'), -el-nes (meagolnes earnestness'), -en-nes (frēcennes 'harm'), -end-nes (älīesednes 'redemption'), -ende-nes (bālwendnes 'salubrity'), -ere-nes (gīfernes 'greediness'), -ett-nes (ärfoestnes 'virtue'), -fealdnes (felafealdnes 'multitude'), -ful-nes (carfulnes 'care'), -hād-nes (geoguðhādnes 'state of youth'), -ig-nes (èadignes 'happiness'), -ing-nes (līhtingnes 'lightness of taxation'), -isc-nes (menniscnes 'state of human'), -lāecan-nes (ðrīstlōecnes 'boldness'), -lēas-nes (endelēasnes 'infinity'), -licnes (braedlicnes 'suddenness'), -or-nes (släpornes 'lethargy'), -rā̄dennes (gefērrōednes 'society'), -sum-nes (langsumnes 'length'), -ung-nes (gegearwungnes 'preparation'), -weard-nes (cefterweardnes 'posterity')

Figure 17. Recursive patterns of suffixation containing -nes in final position.

As Figure 17 shows, the most outstanding suffix in final position is -nes, which can be attached to the suffixes -dōm, -el, -els, -en, -end, -ere, -ing, -hād, -r⿳亠㐅冋den, -sum, -ð, -un, -ung.

To continue with the recursive suffixation of nouns, it is worth mentioning that the suffix - $\mathrm{d} / \mathrm{p}$ shows the widest distribution, as it can be followed by the highest number of different suffixes (-dōm, -el, -en, -end, -ere, -ing, -ling, -nes, -rāeden, -scipe). This can be seen in Figure 18.

-ð-dōm (ðēowotdōm 'service'), -ð-el (tihtle 'accusation'), -ð-en (tyhten

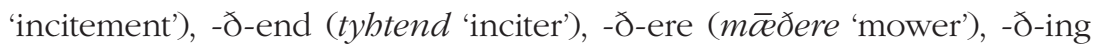
(dèðing 'putting to death'), -ð-ling (ðёowtling 'servant'), -ð-nes (nāhtnes

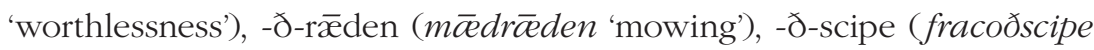
'scandalous conduct')

Figure 18. Recursive patterns of suffixation containing -ð/-p in final position. 
The statement that the number of recursive patterns that an affix enters is directly proportional to its frequency of type also holds for the adjectival suffix -lic, which, being attached to 103 different derivatives, takes part in the recursive combinations presented in Figure 19.

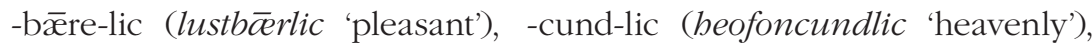
-dōm-lic (wìtedōmlic 'prophetic'), -ed-lic (fracoðlic 'base'), -el-lic (ðrisellī 'tripartite'), -en-lic (crīstenlic 'Christian'), -end-lic (nergendlic 'that should be preserved'), -ere-lic (wōgerlic 'amorous'), -ettan-lic (swöretendlic 'short-winded'), -fæest-lic (ärfaestlic 'pious'), -feald-lic (bundfealdlic 'hundred-fold'), -ful-lic (egesfullic 'terrible'), -ig-lic (éadiglic 'prosperous'), -isc-lic (mennisclic 'human'), -lēas-lic (scamlēaslic 'shameless'), -nianlic (läcnigendlic 'surgical'), -scipe-lic (gesinsciplic 'conjugal'), -sumlic (lufsumlic 'gracious'), -um-lic (furðumlic 'luxurious'), -weard-lic (inweardlic 'internal'), -wīs-lic (rihtwīslic 'righteous').

Figure 19. Recursive patterns of suffixation containing -lic in final position.

As presented in Figure 19, the suffix -lic in final position shows the widest distribution, given that it follows the suffixes -bǣere, -cund, -ed, -en, -ende, -fæest, -feald, -ful, -ig, -isc, -lēas, -ol, -sum, -weard. From the point of view of prefinal suffixation, the suffix -ful can be followed by -lic only and, moreover, it cannot be attached to an already suffixed adjective.

To interpret the information gathered in Figure 17, 18 and 19, distribution in recursivity can be considered from two perspectives, to wit, the quantitative perspective and the qualitative one. The quantitative perspective refers to the number of combinations in which a given affix can partake. The qualitative perspective insists on the positional restrictions that constrain affix combinations. Bearing this distinction in mind, it turns out that the most recursive affix in noun formation (-nes) and the most recursive affix in adjective formation (-lic) cannot occur in prefinal position. The fact that these suffixes are widely used in the contemporary language, as in darkness and bourly, indicates that they were productive in Old English, which suggests that affix productivity in this case coincides with high quantitative recursivity and severe restrictions on qualitative recursivity. It is significant in this respect that double recursivity is restricted to -nes in noun formation (with the exception of frèondlēast 'want of friends' only) and -lic in adjective formation, which may represent another argument in favour of the productivity of these suffixes.

Another suffix that is strictly constrained as to position is -ful. In recursive formations, it can only be followed by -lic and, moreover, it occurs almost without 
exception in prefinal position. This seems to indicate a loss of semantic weight which is compensated by means of the attachment of another suffix, in such a way that the input and the output of the derivational process are, at least, partial synonyms, as is the case with geflitful/geflitfullic 'contentious'.

Another instance of high quantitative recursivity and strict restrictions on qualitative recursivity involves the suffix -ð/-p, which cannot appear in final position following another suffix. Kastovsky (1992: 359) considers the suffix -ð/-p productive in Old Englih because it still appears in words like growth or length. The evidence gathered in this analysis casts doubts on its productivity. The fact that it cannot appear in the final position of a recursive formation probably indicates that it is no longer productive. Suffixations like growth or length seem relics that have remained in the lexicon because the words where they appear have been preserved, rather than because they can still derive new nouns. As for -ð/-p, other suffixes with a distribution higher than the average like -dōm and -end are not constrained as to position because -dōm can be followed by -scipe (ealdordōmscipe 'office of alderman'), -nes ( İ̄ecedōmnes 'cataplasm'), -hād (ðēowdōmhād 'service'), -ere (selfdèmere 'monk subject to his own rules') and -end (selfdèmende 'monk subject to his own rules'), can be followed by -nes (æfterfylgendnes 'succession'), -scipe (frēondscipe 'friendship'),

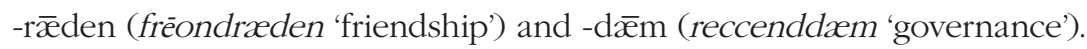

Overall, the conclusion can be reached that strict restrictions on qualitative recursivity indicate productivity if the restrictions apply to the prefinal position whereas they indicate lack of productivity or, at least, low productivity when they apply to final position. It is also worth pointing out that the positional restrictions that arise in suffixation do not apply to prefixation. Indeed, the prefixes un- and healfcan be both final and prefinal in prefixation, thus un-and- (unandwæs 'unskilfull), healf-sine- (healfsinewealt 'semicircular'), on-un- (onunwæsdæm 'folly') and oferhealf- (oferhealfheafod 'crown of the head').

Once the morphological aspects of the problem have been considered, it is necessary to determine what semantic or pragmatic factors restrict the recursivity of nominal and adjectival affixation in Old English.

From the point of view of final affixation, recursivity in prefixation is mainly a matter of intensification (ðurh-, as in ðurhunrot 'very sad'), mitigation (healf-, as in healfsinewealt 'semicircular'; under-, undertōdal 'secondary division') and opposition (un-, as in unandweard 'not present'). From the perspective of prefinal affixation, the set of prefixes allowing for further prefixation coincides practically with the ones just presented as appearing in final affixation, although the oppositive and- (as in unandwiss 'unskillful') and the intensifier sine- (as in healfsinewealt 'semicircular') must be added. 
Turning to suffixation, a remarkable group of affixes in final position comprises those used for forming abstract nouns of entity, property and predication (-dōm, -el, -en, -end, -ere, -ett, -hād, -ing, -ling, -nes, -rǣeden, -scipe, -ung). In Figure 20 an instance of each final suffix in combination with another one in prefinal position is included.

-ig-dōm ( hāligdōm 'holiness'), -ð-el (tibtle 'accusation'), -fæest-en

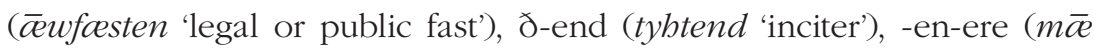
ðere 'mower'), -el-ett (ð̄̄efelett 'thicket'), -ing-hād (ceðelinghād 'princely state'), -ð-ing (dèðing 'putting to death'), -ð-ling (ðёowtling 'servant'), -fulnes (wōhfulnes 'wickedness'), -end-rǣeden (frēondrōeden 'friendship'), -en-scipe (geliefenscipe 'justification'), -or-ung (beolstrung 'darkness')

Figure 20. Final suffixation patterns.

The recursive suffixation of adjectives is practically restricted to the relational suffix -lic in final position. A few examples corresponding to different combination patterns are provided in Figure 21.

-feald-lic ( bundfealdlic 'hundred-fold'), -ful-lic (fäcenfullic 'deceitful'), -ig-lic (mōdiglic 'high-souled'), -sum-lic (angsumlic 'troublesome'), -weardlic (widerweardlic 'contrary')

Figure 21. Recursive patterns of suffixation containing -lic in final position.

These remarks lead to a conclusion on the general function of affixal recursivity as far as the formation of Old English nouns and adjectives is concerned. The function of recursivity in noun formation, considering the evidence gathered in this section, is to coin abstract nouns that denote, above all, abstract concepts. The function of recursivity in adjective formation is, to a large extent, to add nearsynonyms and achieve higher expresivity by means of the recursive adjective. In other words, derivatives can be further derived for semantic reasons (this is the case with the remarkably large number of abstract nouns derived by recursive means from less abstract or concrete nouns) or for reasons, which may be called pragmatic, relating to the achievement of a higher degree of expressivity (this is the case with recursive adjectives). This is consistent with Lieber's (2004: 161) Redundancy Restriction, which bans the semantic content that is already present in the base of derivation and, above all with the idea, also put forward by Lieber (2004), that more affixes can be attached to a previously derived word with the aims 
of transposing a concept or increasing the meaning of the base of derivation. In this case, the formation of abstract nouns and adjectival synonyms is motivated by semantic and pragmatic reasons respectively.

\section{CONCLUSION}

The results of the analysis of nominal and adjectival affixation that has been carried out in this article indicate that recursivity in Old English is mainly a suffixal phenomenon. The analysis has also demonstrated that double recursivity takes place both in prefixation and suffixation, although suffixation is by far the derivational process that produces the highest number of derivatives. In recursive suffixation, a total of fifty-eight combinations of affixes derive nouns, and thirtyeight derive adjectives. The most frequent suffix in noun formation (-nes) and the most frequent suffix in adjective formation (-lic), both occupying a final position in the process of derivation, share the qualitative characteristic of being positionally constrained. None of them can occur in prefinal position. Strict restrictions on qualitative recursivity are an indicator of productivity if these restrictions apply to prefinal positions. On the semantic side, the attachment of affixes to already affixed words is motivated by semantic reasons in the recursive formation of nouns and by pragmatic reasons in the recursive adjectival formations.

\section{REFERENCES}

Jember, G. K., J. C. Carrell, R. P. Lundquist, B. M. Olds and R. P. Tripp. 1975. English-Old English, Old English-English Dictionary. Boulder, Colorado: Westview Press.

Kastovsky, D. 1992. Semantics and vocabulary. In R. Hogg (ed.), The Cambridge History of the English Language I: The Beginnings to 1066. 290-408. Cambridge: Cambridge University Press.

Lass, R. 1994. Old English: a Historical Linguistic Companion. Cambridge: Cambridge University Press.

Lieber, R. 2004. Morphology and Lexical Semantics. Cambridge: Cambridge University Press.

Martín Arista, J. 2008. "Unification and separation in a functional theory of morphology". Investigations of the Syntax-Semantics-Pragmatics Interface. Ed. R. Van Valin. Amsterdam: John Benjamins. 119-145.

Martín Arista, J. 2009. "A Typology of Morphological Constructions". Deconstructing Constructions. Eds. C. Butler and J. Martín Arista. Amsterdam: John Benjamins. 85-115.

Martín Arista, J. 2010a. "OE strong verbs derived from strong verbs". SKASE Journal of Theoretical Linguistics 7-1: 36-56. 
THE RECURSIVE FORMATION OF OLD ENGLISH NON-VERBAL CATEGORIES. PRODUCTIVITY...

Martín Arista, J. 2010b. "Lexical negation in Old English". NOWELE (North-Western European Language Evolution) 60/61: 89-108.

Martín Arista, J. 2011a. "Projections and Constructions in Functional Morphology. The Case of Old English HRĒOW". Language and Linguistics 12 (2): 393-425.

Martín Arista, J. 2011b. "Adjective formation and lexical layers in Old English". English Studies 92 (3): 323-334.

Martín Arista, J. 2012. "The Old English Prefix ge-: A Panchronic Reappraisal". Australian Journal of Linguistics 32 (4): 411-433.

Martín Arista, J. 2013. "Recursivity, derivational depth and the search for Old English lexical primes". Studia Neophilologica 85 (1): 1-21.

Martín Arista, J. 2014. "Noun layers in Old English. Mismatches and asymmetry in lexical derivation". Nordic Journal of English Studies 13 (3): 160-187.

Pounder, A. 2000. Processes and Paradigms in Word-Formation Morphology. Berlin: Mouton de Gruyter.

Quirk R. and C. L. Wrenn. 1994 (1955). An Old English Grammar. DeKalb, Illinois: Northern Illinois University Press.

Torre Alonso, R. 2009. Morphological Process Feeding in the Formation of Old English Nouns: Zero Derivation, Affixation and Compounding. PhD Dissertation, Department of Modern Languages, University of La Rioja.

Torre Alonso, R. 2010. "Morphological process feeding in the formation of Old English nouns". SKASE Journal of Theoretical Linguistics 7: 57-69.

Torre Alonso, R. 2011a. "The Morphological Structure of Old English Complex Nouns". Atlantis 33.1: 127-146.

Torre Alonso, R. 2011b. "Nominal Affix Combinations in Old English: Distribution and Restrictions". RESLA 24: 257-278.

van der Hulst, H. 2010. Recursion and Human Language. Berlin: Mouton de Gruyter. 